\title{
Effects of $\beta$-2 Agonist on Hepatic Glycogen Metabolism in the Fetal Lamb
}

\author{
DAVID WARBURTON, LANCE PARTON, SUE BUCKLEY, LINA COSICO, AND TERRY SALUNA \\ Division of Neonatology and Pediatric Pulmonology, Department of Pediatrics, University of Southern California \\ School of Medicine, Children's Hospital of Los Angeles, Los Angeles, California 90027
}

\begin{abstract}
To determine the effects of fetal $\beta-2$ agonist exposure on fetal hepatic glycogen metabolism, we infused ritodrine at a rate of $1.3 \pm 0.4 \mu \mathrm{g} / \mathrm{kg} / \mathrm{min}$ (mean $\pm \mathrm{SD}$ ) for $24 \mathrm{~h}$ into six chronically catheterized twin fetal lambs starting between 128 and 134 days gestation. The control twins received $0.9 \%$ saline at $1.2 \pm 0.12 \mathrm{ml} / \mathrm{kg} / \mathrm{h}$. In addition, 15 uncatheterized fetuses were killed between 115 and 148 days gestation as unoperated controls. Ritodrine infusion produced a 1.7-fold elevation in fetal serum glucose level, from $23 \pm 5$ to $42 \pm 15 \mathrm{mg} / \mathrm{dl}$, and a 2-fold elevation in serum insulin level, from $16 \pm 5$ to $34 \pm 8 \mathrm{mg} /$ $\mathrm{ml}, \boldsymbol{p}<0.01$. Hepatic glycogen content increased 7 -fold in the uncatheterized controls between 115 and 148 days gestation $(r=0.9, p<0.001)$. Ritodrine infusion reduced hepatic glycogen content by $50 \%$ from $179 \pm 19 \mu \mathrm{g} / \mathrm{mg}$ in twin controls to $90 \pm 25 \mu \mathrm{g} / \mathrm{mg}$ in the ritodrine-infused twins, $p<0.001$. Hepatic glycogen phosphorylase kinase activity was elevated 1.3 -fold from $0.149 \pm 0.100 \mathrm{mU} / \mathrm{mg}$ protein in control twins to $0.186 \pm 0.007 \mathrm{mU} / \mathrm{mg}$ protein in the ritodrine infused twins, $p<0.001$. Glycogen phosphorylase a activity was also increased 1.4-fold from 8.60 $\pm 0.76 \mathrm{nM} \mathrm{NADPH} / \mathrm{min} / \mathrm{mg}$ protein in control twins to $11.85 \pm 0.68 \mathrm{nM} \mathrm{NADPH} / \mathrm{min} / \mathrm{mg}$ protein in the ritodrine infused twins, $p<0.001$. There were no significant differences in hepatic total glycogen phosphorylase $(a+b)$ activity, active (I) or total I + D) glycogen synthase activity, protein, or DNA content between the ritodrine treated and control twins or between the control twins and the uncatheterized control fetuses. We conclude that $\beta-2$ agonist depletes hepatic glycogen in fetal lambs through activation of glycogen phosphorylase by glycogen phosphorylase kinase. Depletion of hepatic glycogen may be an unrecognized side effect of fetal $\beta-2$ agonist exposure. (Pediatr Res 24: 330-332, 1988)
\end{abstract}

Beta sympathomimetic drugs are used in obstetric practice to inhibit premature labor because of their tocolytic action on uterine smooth muscle $(1,2)$. However, neonates born to mothers infused with $\beta$-agonists may experience hyperinsulinemia and hypoglycemia $(3,4)$.

Tenenbaum and Cowett (5) showed that infusion of the $\beta-2$ agonist ritodrine into neonatal lambs results in increased glucose production as well as increased insulin secretion, and speculated that the former may be due to hepatic glycogenolysis. However, Siimes and Creasy (6) reported that infusion of ritodrine into

Received March 24, 1988; accepted May 10, 1988

Correspondence David Warburton, B.Sc., M.B., M.R.C.P., Division of Neonatology and Pediatric Pulmonology, Children's Hospital of Los Angeles, P.O. Box 54700, Los Angeles, CA 90027.

D. W. was supported in part by NIH SERCA 5 K01 AM 01130. L. P. was a fellow of the Children's Hospital of Los Angeles Medical Group. fetal lambs results in increased serum glucose levels with elevation of serum lactate and pyruvate concentrations, and attributed these effects to increased glycolysis.

Hepatic glycogen deposition and mobilization are regulated by the relative activities of glycogen synthase and glycogen phosphorylase, which are in turn regulated by phosphorylase kinase and protein phosphatase-1 (7). Phosphorylation of glycogen phosphorylase by phosphorylase kinase activates glycogen phosphorylase, thereby increasing the rate of biodegradation of glycogen. In contrast, phosphorylation of glycogen synthase by phosphorylase kinase deactivates glycogen synthase, thereby decreasing the rate of glycogen biosynthesis. Protein phosphatase1 dephosphorylates glycogen phosphorylase and glycogen synthase, respectively, decreasing and increasing enzyme activity.

The purpose of our study was to determine the effects of fetal ritodrine exposure on hepatic glycogen metabolism.

\section{MATERIALS AND METHODS}

Animal preparation. Between 120 and 124 days gestation (term is 148 days), six time-dated pregnant ewes were operated on under epidural anesthesia as described previously in detail (8). Catheters were placed in a fetal carotid artery, jugular vein, and the trachea. After the operation the fetuses received $200,000 \mathrm{U}$ of penicillin and $10 \mathrm{mg}$ kanamycin intravenously every day, and the ewes received 1.2 million $U$ of procaine penicillin and $1 \mathrm{~g}$ of kanamycin intramuscularly daily for 5 days. The fetuses were allowed to rest for 7 days or longer before ritodrine was infused.

Ritodrine infusion. Ritodrine hydrochloride was infused intravenously into one of each pair of twin fetuses at a rate of $1.3 \pm$ $0.4 \mu \mathrm{g} / \mathrm{kg} / \mathrm{min}$ (mean $\pm \mathrm{SD}$ ) for $24 \mathrm{~h}$ starting between 128 and 135 days of gestation. The rate of ritodrine infusion was chosen to be similar to the rate of administration recommended for pregnant women $(1,2)$. The other twin served as a control. The infusion vehicle was $0.9 \%$ saline and was given at $1.2 \pm 0.12 \mathrm{ml} /$ $\mathrm{kg} / \mathrm{h}$.

Sample collection and analysis. Arterial blood samples (3.0 $\mathrm{ml}$; approximately $1 \%$ of fetal blood volume) were obtained every 48 to $72 \mathrm{~h}$ up to 127 days gestation and then daily. Arterial blood gases were measured at $39^{\circ} \mathrm{C}$ using a Corning $178 \mathrm{blood}$ gas analyzer (Corning Medical and Scientific, Medford, MA). Serum was separated from the arterial blood and stored at $-40^{\circ}$ $\mathrm{C}$ for subsequent analysis. Serum glucose concentration in $\mathrm{mg} /$ dl was measured by the glucose oxidase method using a YSI-23A glucose analyzer (Yellow Springs Instruments, Yellow Springs, $\mathrm{OH})$. Serum insulin was measured by double antibody radioimmunoassay by a modification of the method of Hales and Randle (9).

The fetuses were removed from the uterus $24 \mathrm{~h}$ after the start of ritodrine infusion, immediately after euthenasia of the ewe and fetuses with sodium pentobarbital. The liver was rapidly removed, cut into small pieces, and frozen in liquid nitrogen. The pieces were stored at $-70^{\circ} \mathrm{C}$ for subsequent analysis. The 
biochemical assays reported below were consistent and stable over a period of months. In addition, 15 uncatheterized fetuses were sacrificed between 115 and 148 days gestation to provide comparative data on the ontogeny of fetal hepatic glycogen metabolism.

Glycogen phosphorylase activity and glycogen content. Glycogen phosphorylase (EC 2.4.1.1) activity of tissue homogenate was assayed by measuring the rate of NADPH generation using the method of Schwartz et al. (10). Glycogen content was analyzed by the method of Lowry and Passoneau (11) in which NADPH generation from glucose-6-phosphate is measured fluorimetrically.

Glycogen synthase activity. Glycogen synthase (EC 2.4.1.11) activity of tissue homogenates was assayed by measuring the incorporation of $\left[{ }^{14} \mathrm{C}\right]-U D P G$ glucose into glycogen as described by Eisen et al. (12) and Thomas et al. (13).

Phosphorylase kinase activity. Phosphorylase kinase (EC 2.7.1.38) activity of tissue homogenates was assayed following the procedure of Hardie and Cohen (14), wherein phosphorylase kinase phosphorylates phosphorylase $\mathbf{b}$, activating it to phosphorylase a. Activation of phosphorylase $\mathbf{a}$ is then measured in a subsequent incubation by following the release of inorganic phosphate from glucose-1-phosphate colorimetrically.

Protein and DNA content. Protein content was measured using the method of Markwell et al. (15) using bovine serum albumin as the standard. DNA content was measured using the fluorimetric technique of Erwin et al. (16).

Statistical methods. Comparisons between the ritodrine treated and control twins were made using the paired $t$ test. A computer modeling technique (Vidichart, Interactive Microware, State College, PA) was used to fit a least squares curve correlation between gestational age and glycogen. Statistical significance was present when $p<0.05$. The data are expressed as the mean \pm SD.

\section{RESULTS}

The effects of ritodrine infusion on fetal blood gases and plasma glucose have been published in detail (8). Briefly, ritodrine infusion was associated with a 1.7 -fold elevation in serum glucose level from $23 \pm 5$ to $42 \pm 15 \mathrm{mg} / \mathrm{dl}$ (mean $\pm \mathrm{SD}$ ). Serum insulin was elevated 2-fold from $16 \pm 5 \mu \mathrm{U} / \mathrm{ml}$ in the controls to $34 \pm 8 \mu \mathrm{U} / \mathrm{ml}$ in the ritodrine infused twins $(p<0.001)$. Fetal glucose and insulin levels before ritodrine infusion were not significantly different from the corresponding values in the control twins. Fetal hepatic protein and DNA content in the ritodrine-treated fetuses were not significantly different from control values.

The effects of ritodrine on hepatic glycogen content and on the activities of glycogen phosphorylase, glycogen synthase, and phosphorylase kinase are shown in Figures 1-4.

Hepatic glycogen content in uncatheterized controls increased 7 -fold from $38 \mu \mathrm{g} / \mathrm{mg}$ tissue at 115 days gestation to $294 \mu \mathrm{g} / \mathrm{mg}$

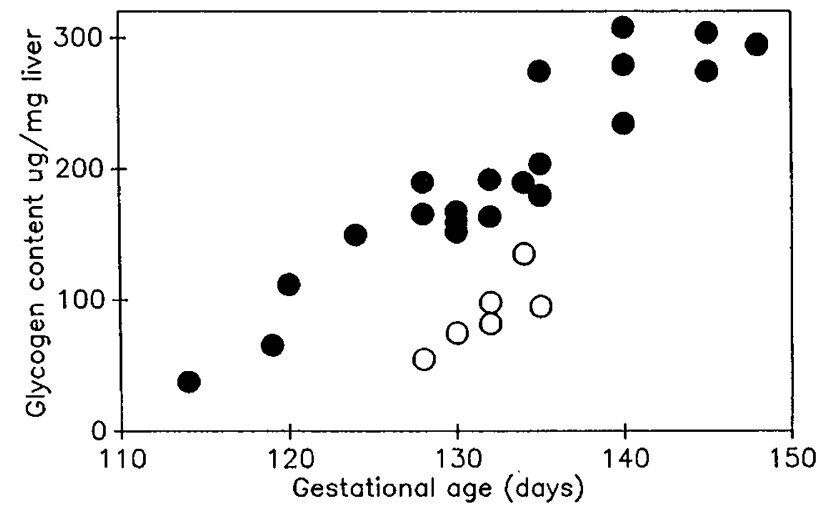

Fig. 1. Comparison of hepatic glycogen content in control $(\bullet)$ and ritodrine-infused $(O)$ fetal lambs.

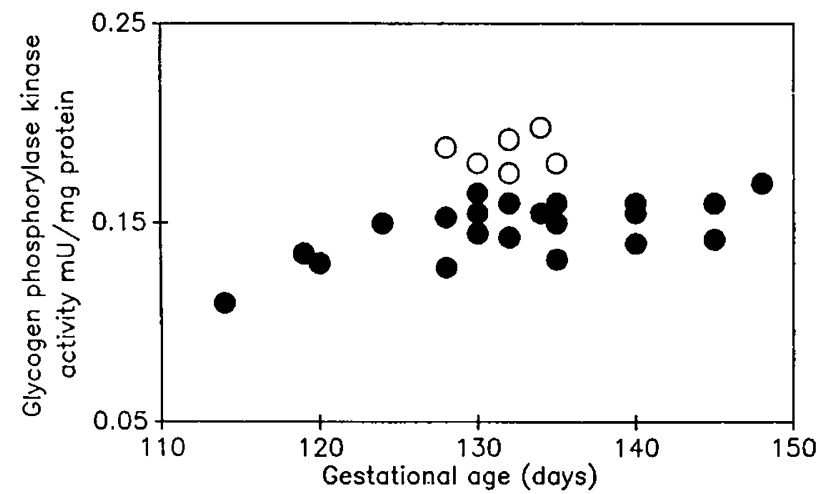

Fig. 2. Comparison of hepatic glycogen phosphorylase kinase activity in control $(\bullet)$ and ritodrine-infused $(O)$ fetal lambs.

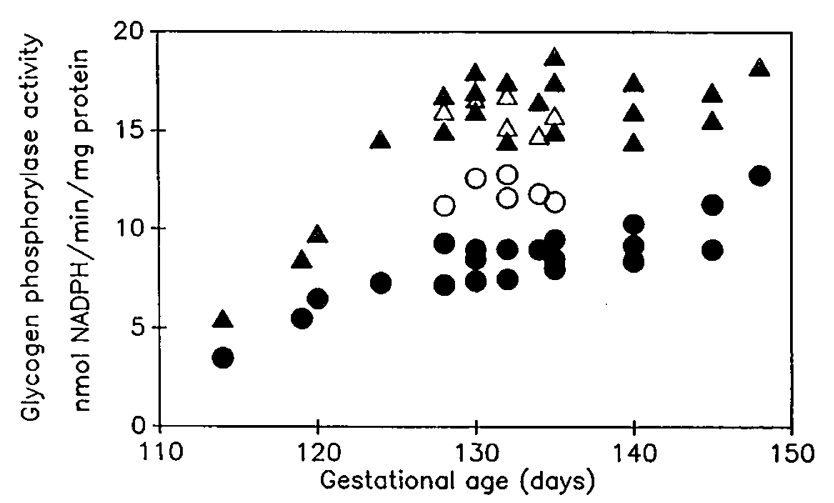

Fig. 3. Comparison of hepatic active glycogen phosphorylase a activity in control $(\bullet)$ and ritodrine-infused $(O)$ fetal lambs, and of total glycogen phosphorylase activity $(\mathbf{a}+\mathbf{b})$ in control $(\bullet)$ and ritodrineinfused $(\Delta)$ fetal lambs.

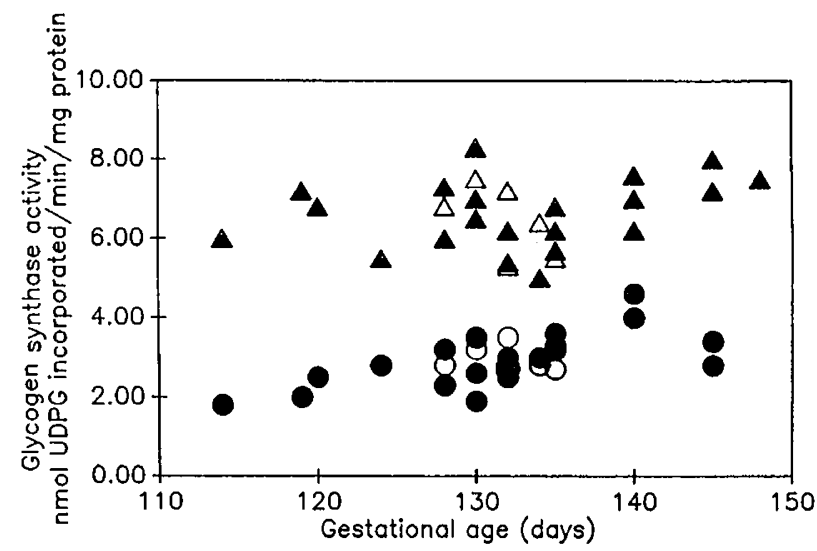

Fig. 4. Comparison of hepatic active glycogen synthase activity (I) in control $(\bullet)$ and ritodrine-infused $(O)$ fetal lambs, and of total glycogen synthase activity $(I+D)$ in control $(\Delta)$ and ritodrine-infused $(\Delta)$ fetal lambs.

tissue at 148 days gestation $(r=0.9, p<0.001)$. Thus, hepatic glycogen content increased with gestational age during the latter third of fetal lamb gestation. The effects of $\beta-2$ agonist were superimposed on this relationship. Hepatic glycogen content in the ritodrine-treated twins, $90 \pm 25 \mu \mathrm{g} / \mathrm{mg}$ tissue, was reduced $50 \%$ in comparison with $179 \pm 19 \mu \mathrm{g} / \mathrm{mg}$ tissue in the twin controls, $p<0.001$. Hepatic glycogen content in the twin controls was not different from the uncatheterized fetal hepatic glycogen content at the same period of gestation.

Hepatic glycogen phosphorylase kinase activity in the ritodrine-treated fetuses, $0.186 \pm 0.007 \mathrm{mU} / \mathrm{mg}$ protein, was ele- 
vated 1.3-fold above the activity in the livers of the control twins, $0.149 \pm 0.010 \mathrm{mU} / \mathrm{mg}$ protein, $p<0.001$. Hepatic glycogen phosphorylase kinase activity in the twin controls was not different from the activity in the livers of the uncatheterized fetuses.

Glycogen phosphorylase a activity in the livers of the ritodrine treated fetuses, $11.85 \pm 0.68 \mathrm{nM}$ NADPH$/ \mathrm{min} / \mathrm{mg}$ protein, was increased 1.4-fold in comparison with the activity of $8.60 \pm 0.76$ $\mathrm{nM}$ NADPH $/ \mathrm{min} / \mathrm{mg}$ protein in the control twins, $p<0.001$. There were no significant differences in total glycogen phosphorylase $(\mathbf{a}+\mathbf{b})$ activity or in active $(\mathrm{I})$ or total $(\mathrm{I}+\mathrm{D})$ glycogen synthase activity between the ritodrine treated and the control twins or between the control twins and the uncatheterized control fetuses. Thus, $\beta-2$ agonist stimulation depleted fetal hepatic glycogen content by activation of phosphorylase kinase, which in turn increased the fraction of glycogen phosphorylase in the active (a) state.

\section{DISCUSSION}

The rate of ritodrine infusion in our study was chosen to be similar to the recommended rate of administration of ritodrine to pregnant women $(1,2)$. The effects of this infusion on fetal blood gases, plasma glucose, pulmonary surfactant, lung mechanics, and lung metabolism have been reported previously $(8$, 17).

Glycogen deposition and mobilization are regulated by the relative activities of glycogen phosphorylase and glycogen synthase, which are in turn regulated by the calcium-calmodulindependent enzyme termed phosphorylase kinase (7). Hepatic glycogen deposits accumulate during fetal life, indicating that the ontogenic regulation of the activities of glycogen phosphorylase and glycogen synthase favors glycogen biosynthesis (10). However, we report that infusion of ritodrine into fetal lambs between 128 and 135 days gestation results in depletion of hepatic glycogen to levels similar to those seen below 125 days gestation. Thus $\beta-2$ agonist stimulation favors glycogen biodegradation in the fetal liver.

Hormones, including glucagon, epinephrine, norepinephrine, and vasopressin, all have been reported to act as physiologic stimuli of hepatic glycogenolysis (18). The increased activities of glycogen phosphorylase kinase and of glycogen phosphorylase a in fetal liver homogenates suggest that known $\beta$-adrenergic agonist pathways involving phosphorylation of glycogen phosphorylase were responsible for the depletion of hepatic glycogen (7, $10)$. However, glycogen synthase activity was unchanged after $\beta$ 2 agonist stimulation. The activity of protein phosphatase- 1 was not measured.

Hyperinsulinemia and hypoglycemia have been reported in infants whose mothers received ritodrine infusion shortly before delivery $(3,4)$. In our study, fetal ritodrine exposure was associated with fetal hyperglycemia, hyperinsulinemia, and hepatic glycogen depletion. Inasmuch as ritodrine crosses the human placenta $(19,20)$, depletion of fetal hepatic glycogen reserves may be an unrecognized side effect of fetal ritodrine exposure.

Acknowledgments. Ritodrine hydrochloride was a gift of Astra Pharmaceutical. Mary DiNallo provided secretarial assistance.

\section{REFERENCES}

1. Barden TP, Peter JP, Merkatz IR 1980 Ritodrine hydrochloride: a beta mimetic agent for use in preterm labor. I. Pharmacology, clinical history, administration, side effects and safety. Obstet Gynecol 56:1-6

2. Merkatz IR, Peter JB, Barden TP 1980 Ritodrine hydrochloride: a beta mimetic agent for use in preterm labor. II. Evidence of efficacy. Obstet Gynecol 56:711

3. Epstein MF, Nicholis E, Stubblefield PG 1979 Neonatal hypoglycemia after betasympathomimetic tocolytic therapy. J Pediatr 94:449-451

4. Procianoy RS, Pinheiro CEA 1982 Neonatal hyperinsulinemia after short term maternal beta sympathomimetic therapy. J Pediatr 101:612-614

5. Tenenbaum D, Cowett RM 1985 Mechanisms of beta sympathomimetic action on neonatal glucose homeostasis in the lamb. J Pediatr 107:588-592

6. Siimes AS, Creasy RK 1980 Maternal and fetal responses to Ritodrine in the sheep. Acta Obstet Gynecol Scand 59:181-186

7. Cohen PC 1985 The role of protein phosphorylation in the hormonal control of enzyme activity. Eur J Biochem 151:439-449

8. Warburton D, Parton L, Buckley S, Cosico L, Saluna T 1987 Effects of beta-2 agonist on tracheal fluid flow, surfactant and pulmonary mechanics in the fetal lamb. J Pharmacol Exper Therap 242:394-398

9. Hales CN, Randle PH 1963 Immunoassay of insulin with insulin antibody precipitates. Biochem J 88:137-145

10. Schwartz AL, Raiha NCR, Rall TW 1975 Hormonal regulation of glycogen metabolism in human fetal liver. 1. Normal development and effects of dibutyryl cyclic AMP, glycogen, and insulin in liver explants. Diabetes 24:1101-1112

11. Lowry OH, Passoneau JV 1972 A Flexible System of Enzymatic Analysis Academic Press, New York

12. Eisen HJ, Goldfine DI, Glinsmann WH 1973 Regulation of hepatic glycogen synthesis during fetal development: roles of hydrocortisone, insulin and insulin receptors. Proc Natl Acad Sci USA 70:3454-3457

13. Thomas JA, Schlender KK, Larner JA 1968 A rapid filter paper assay for UDP glucose-glycogen glucosyltransferase, including an improved biosynthesis of UDP-14C-glucose. Anal Biochem 25:486-499

14. Hardie DG, Cohen $P 1983 \mathrm{Ca}^{2+}$ - and calmodulin-dependent protein kinase. In: Bergmeyer HU (ed) Methods of Enzymatic Analysis, vol III. Verlag Chemie, Weinheim, FRG, pp 487-495

15. Markwell MA, Haas SM, Bieber LL, Tolbert NE 1978 A modification of the Lowry method to simplify protein determinations in membrane and lipoprotein samples. Anal Biochem 87:206-210

16. Erwin BG, Stoschek CM, Florini JR 1981 A rapid fluorimetric method for the estimation of DNA in cultured cells. Anal Biochem 110:291-294

17. Warburton D, Parton L, Buckley S, Cosico L, Saluna T 1987 Effects of beta 2-agonist on metabolic regulation in the fetal lamb lung. J Pharmacol Exper Therap 242:389-393

18. Hems DA, Whitton PD 1980 Control of hepatic glycogenolysis. Physiol Rev $60: 1-50$

19. Kleinhout J, Veth AFL 1975 Placental transfer of ritodrine and its effects on the fetal cardiovascular system. In: Eshes TKAB, de Haan J, Van Kessel H (eds) Aspects of Obstetrics Today. Excerpta Medica, Amsterdam, pp 385395

20. Gandar R, de Zoeten LW, van der Schoot JB 1980 Serum level of ritodrine in man. Eur J Clin Pharmacol 17:117-125 